\title{
A Case Study on the Influence of Organizational Culture
}

\section{on Language Classroom}

\author{
Zhihui Liu \\ English Department, XiangNan University \\ Chenzhou 423000, China \\ E-mail: ouypx@sohu.com
}

\begin{abstract}
This paper tries to probe the influence of the organizational culture on language classroom at a newly-established local college. It firstly reviews the knowledge of the organizational culture and finds out its features, and then discusses how the organizational culture was greatly influenced by the host educational environment. On the basis of this, the paper interprets how organizational culture in turn influences the classroom culture in terms of English language teaching and learning in China.
\end{abstract}

Keywords: Organizational culture, Influence, Language classroom

\section{Introduction}

With the development of economy and society, and in view of the urgent need of different kinds of high-level practical and compound personnel in the field of modernization construction, China speeds up the reform of higher education in order to develop a modern education system applicable to the socialist market economy. In the meantime, as another feature of the educational reform, the major curricula of school education and of tertiary English, both initiated by the Ministry of Education, have been reviewed and revised again and again. As a result of the reviewing processes, three new English language curricula have been produced and put to experiment: National Curriculum for English language teaching(ELT) for Compulsory education, National Curriculum for ELT for Senior Middle School Education, and Curriculum Requirements for University Non-major English Education. Together with the introduction of new curricula, the training of enough qualified English teachers has been adequately addressed with a view to improve the teaching quality of ELT in the countryside schools. The specific objective of the program was "to introduce them [teacher trainees] to new ideas in the theory and practice of English language teaching, particularly to the communicative language approach and the learner-centered classroom" (Ward, 1995:14). A more general objective was to narrow the gap between the urban cities and rural regions in education (Ouyang, 2000).

Now we're thinking whether it is effective or just a waste of human and material resource to take a top-down reform with little regard to regional differences, and whether teacher training programs that prepare teachers for such reform should be focused on methodological aspects or on the social contexts in China. A further question is why it is important to think about language teaching and learning beyond the immediate classroom in view of a wider society. Therefore, we choose this topic to probe the influence of the organizational culture on language classroom at a newly-eatablished local college.

\section{The definition of the organizational culture and the characteristics of our organizational culture}

As Schein (1997) and Seihl (1985) clearly note in their seminal article on organizational culture, organizational culture is 'a product of the experience of social groups'. And Prosser (1999:11) identifies 'organizational culture' as 'a collection of theories that attempt to explain and predict how organizations and people in them act in different circumstances' and as 'a way of looking at and thinking about behavior of and in organizations, and offers a useful perspective for understanding what is occurring in school and other kinds of educational institutions...' Therefore, organizational culture is: 'the interweaving of the individual into a community and the collective programming of the mind that distinguishes members of one known group from another. It is the values, norms, beliefs and customs that an individual holds in common with members of the social unit or groups' (Ogbonna,1993:42). According to Schein's(1980) model of organizational culture, which has become an influential theory of organizational culture, beliefs and assumptions form the core of an organization's culture.

From the reviewing, we find that not a single definition can interpret 'organizational culture' theory appropriately; but we believe that one way that researchers have tried to understand what a culture means is to find ways to identify the types of 'assumptions' that underlie organizational cultures and try to make sense of these assumptions. When we tried to identify the types of 'assumptions' that underlie our organizational cultures, we found that it's a special integration. 
Firstly, with government control over higher education diminishing, universities and colleges are given more powers to determine their own management style. Therefore, the president is responsible for the overall management of the university and plays a decisive role. He may enforce a series of rules and regulations, and exercise direct supervision to oversee and control the work of the departments and the way they interact. Thus, he is stereotyped as a bureaucracy, which is the typical example of the Role Culture.

Secondly, the university is job or project oriented. It is the most important thing for the university administration to strongly promote the quality of graduate education, and standardize systematic management so as to go through the initial examination and re-examination for the admission and training of graduates, and for degree conferment, which is approved by the Disciplines Appraising Groups organized by the Academic Degree Committee of the State Council. And then the disciplines and specialties, and even the number of the teachers with postgraduate degrees are subject to re-examination and approval.

Thirdly, the university seems to be more oriented toward individualism and utilitarianism. In order to develop a modern education system of higher learning applicable to the socialist market economy, reforms allow colleges and universities to be run by themselves or by non-governmental bodies under government macro-management. Now the old practice of government alone financing institutions of higher learning is being replaced by a new one, and, accordingly, the government budget remains the main part while diversified sources provide the remainder. Up to this point, the university has to raise more funds to improve the infrastructure and to realize the diversifying. Thus, the University has been actively pioneering the flexibility in enlarging the recruitment of students irrespective of their different levels, which may include some short courses for special purposes.

To sum up, as a newly-established local college, influenced greatly by the host educational environment, our university no doubt will be job oriented and utilitarianism with very clear characteristic of "the Role Culture" [Note 1]and " the Task Culture"[Note 2].

\section{English language learning and teaching in China}

On the institutional level, English is not only the core course which is responsible for training the pre-service English teacher at the secondary school, but also a compulsory subject for non-major graduates which helps them to get B. A. We have to emphasize here that College English Test (CET or, Band-4 and-6 tests), known as the English proficiency tests, plays an important role in higher education in China. First, Bachelor degrees are only conferred to those who succeed in CET. Second, without test certificates many government institutions and private companies will refuse to accept the applicants. As a result, many universities in China, including ours, have been forced to lay emphasis on the test scores and turn teaching and learning into a sort of test-oriented education. Hence there is a dilemma for all the teachers: to be students-oriented or to be test-oriented? With the exception of this, the ever-increasing demand for English proficiency provides the university with great opportunities to make profit. In this case, our university encourages the teachers to be flexible in teaching method to meet different learners' various needs. Therefore, ELT is seen as a key to realise two objectives: one for degree conferment, another for economic development. So whatever teachers do should serve these purposes.

On the national level, English is perceived by the government as a necessary means for helping the nation to further open up, a valuable resource for realizing its modernization program and an important cornerstone of international competition. This led to the change of English education. According to the latest national syllabuses, the new conceptions of ELT represent a departure from the traditional teacher-centered and textbook-driven teaching in the sense that they highlight a learner-oriented, educational approach, with a view to bring about character education in general and to develop the learner's ability to use English in communication in particular (Wu , 2002). While English learning is stressed in relation to the rapid development of information technology, the globalization of economic activities and the basic abilities that citizens in the $21^{\text {st }}$ century must possess. Owing to these ambitious objectives, teachers are required to give priority to the students' development of communicative competence, to strive for an all-round development of listening, speaking, reading and writing skills, to encourage active learner participation in the learning process, and to develop learner autonomy. In addition, to cope with the aims of the new courses of study, teachers are expected to move in the direction of adoption of the communicative language teaching approach. It is hoped that it will give classroom teachers more freedom within the framework of the curriculum, and this will in turn lead to more progressive methodologies and practices to be adopted. Indeed, the Ministry itself see the new curriculum as a means to force teachers to change their classroom practices and thereby better help learners to develop the ability to use the language to communicate competently. Yet many of the teachers themselves still do not have a high level of communicative competence in the language. In addition, there is a general lack of teacher education. While the situation is beginning to change with more and more language teachers seeking training, it is still possible for a teacher to become certified to teach English on the basis of obtaining a bachelor's degree or a master's degree, and to participate in outside in-service training and retraining activities. Therefore, short courses are offered by government at all education levels. 


\subsection{Classroom behavior}

As ours is a normal university, it was selected to host the in-service training program at the regional level. In the summer of 2005, we were assigned to teach an English listening and speaking course for the Junior Middle School English Teacher Training program ("junior" here refers to the first three years in the six-year secondary school system) for a month, which is designed to cover 80 class hours of instruction. There were at least 40 teachers coming from the remote, less developed counties. In these areas, the prevailing methodology was a teacher-centered, grammar -translation pedagogy; the quality of ELT was at its lowest. From their brief self-introductions made in class and our close interviews with them after class, we found that there are big differences among them. Some were originally teachers of other subjects other than English and they became English teachers because of the serious shortage. Others are teachers of English majors who have received some formal training in the normal college. Obviously, big gap exists in the trainees' English proficiency level.

The teaching materials-- "True Colors", assigned by the institutional administration, is an excellent textbook for such short course training, especially for adult or young adult course in English as a foreign language. According to the writers, Jay Maurer and Irene E. Schoenberg (2003), the book presents the true voice of the native speakers of American English, and systematically teaches students to communicate in their own words- "to let their true colors shine through." As a major innovation of this book, it systematically builds students' ability to present their own ideas, opinions, and feelings - both accurately and confidently. To us, it is just like a beam of sunshine in cold winter.

As mentioned above, our university gives the teacher enough freedom in practical teaching. We can design teaching goals and choose teaching method on our own. So we designed four goals according to the objectives of this training, which guided what went on in our class:

- Teacher trainees should be actively involved in their interactive activities.

- Teacher trainees should acquire communication skills as a result of being engaged in authentic language use.

- Teacher trainees should master two essential listening skills: determining context and focusing attention.

- Teacher trainees should be able to present their own ideas, opinions and feelings accurately and confidently.

In order to provide the trainees with more exposure to English, and in consideration of the trainees' different levels, we chose the communicative teaching method (CLT) with the help of visual-audio-lingual method rather than the task-based language teaching suggested by the textbook. We made our teaching plan in detail and divided our teaching procedure into three main parts:

Part 1 Social language and grammar lesson included conversation and pair practice. In this part, we began with a short dialogue presentation, and followed with a modeling of important social language through videocassette playing while providing clear and well-explained grammar presentations integrated with the social language, before we encouraged the trainees to manipulate it. The same dialogue was repeated later, when the trainees were asked to personalize the social language in pair practice.

Part 2 "In their Own Words" In this part, trainees watched and listened to a short passage which centered on two essential listening skills --- determining context and focusing attention. Trainees are required to do some listening comprehension exercises orally and, on the base of this, some of them were asked to retell this short passage.

Part 3 "Heart to Heart" This part always came near the end of the unit, ensuring adequate preparations for success, since the trainees were encouraged to express their own opinions, ideas and feelings on a variety of topics.

In addition, we made a very good use of the audio and video cassettes of this course and a multi-media language lab as well, even to the extent that we downloaded some additional listening texts. It seemed that everything was ready and we were confident of our teaching.

However, things turned out contrary to our wishes. And in this regard, three episodes that happened in the classroom can serve as a demonstration.

Scene 1 At the very beginning of our class, we divided the trainees into five groups in order to facilitate real communication and naturalistic language use. We tried to begin each class with a warm-up activity so that the trainees could interact and communicate with each other in English more actively. At the same time a discussion was held before the trainees watched the video, which was intended to help them follow the video more easily. During the small group work and pair practice, we walked around and monitored the trainees, leaving them as unperturbed as possible. To our surprise, we found that they slipped back into using the Chinese or even dialects. And when they realized our monitoring, they stopped talking altogether. The problem became even more complicated when we asked representatives from the small groups to report on their work --- no one wanted to be a volunteer. Nevertheless, when we went on with the class by asking some questions, they were active in answering in chorus.

Scene 2 In the listening comprehension section, even though the trainees could finish the written work as quickly as 
possible with the help of listening skills introduced, some of them still asked me to read the script and translate them into Chinese, because they wanted to know the detailed meaning in Chinese.

Scene 3 When we tried ourselves to speak English in class and persuaded the trainees to communicate with each other in English, they said to me that, "we all know it's useful for us to learn the language by communication, but we don't think it's useful for the examination. On one hand, if you speak English all the time in class, we couldn't follow you; on the other hand, if we give all the instruction in English, our students couldn't understand, and of course they will fail in the examination. So why should we be trained in this way?" What's more, they worried a lot about the achievement test we will give them at the end the training program.

After these episodes, we changed our teaching plan accordingly. We spent most of our time primarily listening to and watching the video. The rest of the time was spent on helping them understand the message given by the video, and providing the information that the trainees specifically asked for. Our classroom changed from monolingual to bilingual. No complaint emerged.

\subsection{Interpretation of the classroom behavior}

The short course training didn't go as we had planned. As English teacher trainers (to some extent), we attempted to interpret the classroom behavior in terms of our own cultural setting and seek for contextual explanations. As the literature defines, the classroom is situated in a host institution, which is in turn situated within a host educational environment. Therefore, the host educational environment will influence the host institution and in return, the classroom. Bowers (1987:9) have pointed out that "the classroom is a microcosm which, for all its universal magisterial conventions, reflects in fundamental social terms the world that lies outside the window".

With regard to our organizational culture, the function a university actually performs is the result of compromise between what is needed and what is demanded (Coleman, 1996). In other words, functionalism is a substitute for utilitarianism. Though we have seen ourselves as sensitive teachers, we have been familiar with various teaching approaches such as: whether old or young, traditional or advanced, grammar-translation method, the audio-oral method, the visual-audio-oral method, the pattern-and-drill approach and the communicative approach, and so on, we have never studied and used rootedly any of them systematically from start to end, that is, from primary school education to college education, from teachers' learning and teaching to student learning. Immersed by the instrumental function of the university environment, for us, English language teaching is becoming a so-called "task-based" work. On one hand, we have been kept busy with our teaching on our routine life because of the rapid-increasing enrollment of students; on the other hand, we teachers want to grasp the opportunity granted by the university to get higher degree through further education, and then we spend most of our time on the preparation for the entrance examination. Thus, it would be difficult for us to delve into each methodology, say nothing of sufficient theoretical research. That's why we swung back and forth like a pendulum, from CLT to TM, from students-centered, the modern and advanced way, to teacher-centered, the old and traditional one, and vice versa. And such is the result.

With regard to our trainees, if they think their students couldn't understand the instruction given in English, English speaking and listening are not the most basic language skills, and then they don't want to be trained in this communicative way. Furthermore, our trainees assume that it is necessary for them to do some translation work and to give some grammatical explanation in favor of the examination-oriented education, in which the National College Entrance Examination is the compasses in their voyage of English learning and teaching. The last but not the least, there is a general consensus among the trainees that the teacher is a knowledge giver, a what-he-says counts authority as well as a disciplinarian (Ouyang, 2000). Teacher-centered instruction is overwhelmingly an efficient and a successful way as it is, for the primary and secondary schools to face the challenge given by outnumbered students. In other words, the students-centered approach is just an ideal to some extent. From this point, we may find that people think and behave according to their own "thinking". Their thinking is influenced by culture norms and physical environments ((Wedell \& Fairhurst, 2005). And so classroom practices reflect attitudes and beliefs about language and language learning that is embedded in the socicultural context.

It follows from what has been said that both our trainees and we strived for the instrumentally orientation. Thus we see if a university develops towards more practical concerns such as producing better scores and passing rate at important exams; if the trainees bring different experiences, personalities, styles and feelings to a teaching and learning context and be unable to refresh the view in such a short course; if the top-down reform carries out with little regard to regional differences and irrespective of the trainees' different levels, the reform in ELT will turn out to be deficient, that is, to some extent, a waste of human and material resources. Otherwise, it is important for us to think about English language teaching and learning beyond the immediate classroom and relate it to the world outside, as we found that it was so greatly influenced by the host institution and the host educational environment.

\section{Conclusion}

As the literature suggests, if a new curriculum or a set of textbooks based on new approaches are planned and 
introduced into an education system, the success of the planned change depends on the extent to which teachers are able to rethink at least some of their ideas about or expectations of teaching and learning, and adapt their classroom behavior or expectations accordingly. That means teacher training program might take account of the social contexts, which are rooted in our social surroundings and hence have influential effects on many aspects of everyday routine life, educational learning and teaching. The short training course we described here is one example of explaining this idea from our own experience.

One implication here is that teacher education should be seen as a crucial key link in the successful implementation of the reform in changing ELT. Furthermore, successful teacher training or teacher development is a systematic observation and exploration of classroom teaching. In the recognition of promoting the healthy interaction of teaching and learning, we should have a deep understanding of organizational culture and then develop positive attitudes to be more conscious of the development of ELT, and continually readjust and develop in every field. Meanwhile, we could have a clear distinction between teacher training and teacher development, especially at regional level. Especially, in-service education dealing with the on-going professional development of teachers should not only focus on classroom methodologies appropriate for different situations, but also on teacher self-evaluation, teacher belief system and teacher cognition, which is the target of the training programme.

\section{References}

Bowers, R. (1987). Developing perceptions of the classroom: observation and evaluation, training and counselling. In $R$. Bowers (ed.), Language Teaching Education: An integrated programme for EFL teacher training. ELT Document 125. Modern English Publications in association with The British Council.

Coleman, Hywel. (1996). Autonomy and Ideology in the English Language Classroom. In Hywel Coleman (Ed.) Society and the Language Classroom, Cambridge University Press, pp.1-16.

Maurer,Jay and Schoenberg.Irene E. (2005).True Colors. Addison Wesley Longman, Inc., pp. viii-xii.

Ogbonna, E. (1993). Managing organizational culture: Fantasy or reality?. Human Resourse Management Journal, No.3,pp.42-54.

Ouyang, Huhua. (2000).One-Way Ticket: A Storey of an Innovative Teacher in Mainland China Anthropology and Education Quarterly, Vol.31, No.4,pp.397-425.

Prosser, J. (1999). School Culture. London: Paul Chapman Publishing Ltd., pp.11.

Schein, E. H. (1980). Organizational psychology. 3rd Ed. Englewood Cliffs, NJ: Prentice Hall.

Schein, E.H. (1997). Organizational Culture and Leadship. Jossey-Bass, San Francisco.

Seihl C. (1985). After the founder: an opportunity to manage culture. In: Frost, P., Moore, L., Louis. M., Lunberg,C and Martin, J.(eds): Organizational Culture. Beverly Hills,Sage.

Ward A \& Darling L.(1995). Understanding the School Community: A Field-based experience in teacher education. Teaching Education, Vol.6, pp.85-93.

Wedell, Martin and Fairhurst, Gen. (2005). Handout of MA TESOL Course.

Wu Yi'an. (2005). Aspiring after Continued Teacher Development----- A Study of Effective University EFL Teachers in China. Foreign Language in China, Vol. 2.

\section{Notes}

Note 1. The characteristics of the Role Culture

a. It is often stereotyped as a bureaucracy;

b. It is characterized as a Greek temple, a large building whose upper stories and roof are supported by huge stone pillars: these pillars (the departments) of the organization are its strength, and the organization can grow very large;

c. It has clear procedures to control the work of the

departments and the way they interact. Each person understands the roles she/he plays and the appropriate communication channels and the rules for settling disputes.

d. It has managers on the upper stories who co-ordinate activities and engage in planning.

e. It regards job descriptions as more important

than individuals; people are frequently chosen to fit roles.

f. It will succeed as long as there is a stable environment: it does not appreciate, and usually does not respond well to, rapid change: if the environment changes quickly and/ or the ground shake, it can come tumbling down. 


\section{Note 2. The characteristics of the Task Culture}

a. It is job or project oriented and can be presented as net. Some of the strands of the net are stronger than others; a hole in the net can be stretched to a breaking point;

b. It seeks to bring together the human and material resources needed to complete the job and then let individuals get on with it;

c. It has a hierarchy in which influence is widely dispersed and power is based on expertise; day to day control is vested in individuals working on the job rather than on top managers; teamwork is emphasized;

$\mathrm{d}$. It is very adaptable and is appropriate where flexibility and sensitivity to the market or environment are essential;

e. It moves quickly and encourages individual talent: it thrives in a fast-changing environment, but finds it difficult to produce economies of scale or depth of experience.

(Handout of MA TESOL Course, 2005) 